\title{
Agronomic performance and photosynthetically active radiation intercepted by maize intercropped with Brachiaria
}

\author{
Priscila Akemi Makino ${ }^{1}$, Gessí Ceccon ${ }^{2}$, Luan Marlon Ribeiro ${ }^{1}$, Felipe Ceccon ${ }^{1}$ \\ ${ }^{1}$ Universidade Federal da Grande Dourados, Dourados, Mato Grosso do Sul, Brasil. E-mail: priscila_akemi17@hotmail.com, \\ luanmarlon@hotmail.com, felipececcon92@gmail.com \\ ${ }^{2}$ Embrapa Agropecuária Oeste, Dourados, Mato Grosso do Sul, Brasil. E-mail: gessi.ceccon@embrapa.br \\ Received: 11/06/2019; Accepted: 29/10/2019.
}

\section{ABSTRACT}

Maize and soybean are the main crops used for crop yield on Brazilian Cerrado biome. The off-season maize intercropped with ruzigrass [Urochloa ruziziensis (R. Germ. \& C.M. Evrard) Crins (Syn. Brachiaria ruziziensis Germ. \& Evrard)] increases soil cover and yield for crops in succession. However, the benefits on maize yield depend on the distribution and radiation-use efficiency (RUE) and its conversion to biomass. This study aimed to evaluate maize and ruzigrass yield in different cultivation systems. The experiment was carried out at Embrapa Agropecuária Oeste, in Dourados, MS, Brazil. The experiment design was randomized blocks, with seven treatments constituted by the combination of spacing between maize rows, single and intercropped, with ruzigrass in distribution methods. Photosynthetically active radiation, chlorophyll, leaf temperature, morphological characteristics and maize mass yield were evaluated in maize at the flowering stage (R1). Maize and ruzigrass yield were evaluated during maize maturation. The reduced spacing in single maize has a higher yield and lower radiation incidence in the ear. Maize intercropped with ruzigrass sown by broadcasting showed higher leaf temperature, lower plant height and lower maize leaf area. Morphological and physiological characteristics and maize grain yield were more influenced by planting methods than the presence of ruzigrass. The highest yield of dry matter and maize grain occurred in reduced spacing in maize, either alone or intercropped with ruzigrass.

Keywords: Brachiaria ruziziensis, grain yield, photosynthetically active radiation, plants arrangement, Zea mays.

\section{Desempenho agronômico e interceptação da radiação fotossintética de milho em modalidades de consórcio com braquiária}

\section{RESUMO}

O milho safrinha e a soja são as principais culturas utilizadas na exploração agrícola do Cerrado brasileiro. O milho safrinha consorciado com braquiária aumenta a cobertura do solo e influência na produtividade das culturas em sucessão. No entanto, os benefícios na produtividade do milho dependem da distribuição e eficiência de uso da radiação fotossintética e da sua conversão em biomassa. Objetivou-se, então, avaliar a interceptação luminosa e a produtividade de milho e braquiária em diferentes modalidades de cultivo. O experimento foi desenvolvido na Embrapa Agropecuária Oeste, em Dourados - MS. O delineamento experimental foi em blocos casualizados, com sete tratamentos constituídos pela combinação de espaçamentos entrelinhas de milho, em cultivo solteiro e consorciado, com métodos de distribuição da braquiária. No estádio R1 do milho foram avaliados a interceptação da radiação fotossinteticamente ativa, clorofila, temperatura foliar, caracteres morfológicos e a massa seca de plantas de milho. Na maturação do milho, avaliaram-se a produtividade de grãos de milho e a massa seca de braquiária. $\mathrm{O}$ milho solteiro em espaçamento reduzido apresentou maior produtividade de grãos e menor incidência de radiação na espiga. $\mathrm{O}$ milho em consórcio com braquiária a lanço apresentou maior temperatura foliar, menor altura de plantas e menor área foliar. As características morfológicas, fisiológicas e a produtividade de grãos de milho foram mais influenciadas pelas modalidades de cultivo do que pela presença da forrageira. As maiores produtividades de massa seca e de grãos de milho ocorreram no espaçamento reduzido, seja em cultivo solteiro ou em consórcio com braquiária.

Palavras-chave: Brachiaria ruziziensis, produtividade de grãos, radiação fotossinteticamente ativa, arranjos de plantas, Zea mays. 


\section{Introduction}

Grain yield is a complex variable and depends on the genetics interaction, environmental, and management factors (Kappes et al., 2011). Among the environmental factors, the use of light is the most important process for productivity, and in general, the efficiency of solar radiation use by crops is low (Strieder et al., 2008), especially in the autumn-winter season, when these resources are smaller.

One of the ways to optimize light interception and contribute to grain yield increasing is through the appropriate choice of plants density and row spacing (Marchão et al., 2006). By adopting a better plant arrangement, an equidistant distribution, and a better use of environmental resources can be achieved (Kunz et al., 2007). A challenge to be achieved is to identify farming systems that provide good ground cover coupled with greater economic returns, to increase its soil quality and subsequent crop yield.

Among the agricultural systems studied, maizebrachiaria intercropped stands out as an alternative to reach similar yield to single crops and contribute to straw`s increase in satisfying quantities to maintain the no-till system (Jakelaitis et al., 2006; Garcia et al., 2013 and Ceccon et al., 2013b). In addition to diversifying agricultural production on the property, the intercropped inclusion in the crop rotation system improves soil chemical (Loss et al., 2012) and physical (Chioderoli et al., 2012) properties over time, reduces the level of weed infestation on soybean succession areas (Concenço et al., 2013), and favors the break cycles of pests and diseases.

Currently some modalities stand out, such as the use of a brachiaria mid row, considered an option of greater economy and efficiency in the straw production (Ceccon et al., 2013a). Studies about maize plus a forage`s new implement methods, in reduced spacing, can minimize interspecific competition and reduce competition for production factors, maintaining the agronomic viability of the intercropped.

The objective of this research was to evaluate the effects of off-season maize croppping modalities, single and intercropped with ruzigrass [Urochloa ruziziensis (R. Germ. \& C.M. Evrard) Crins] under photosynthetically active radiation interception (PARi), mass and maize grain productivity, and ruzigrass dry mass in a no-till system.

\section{Material and Methods}

The study was carried out in Dourados, Mato Grosso do Sul, Brazil $\left(22^{\circ} 13^{\prime} \mathrm{S}\right.$ and $54^{\circ} 48^{\prime} \mathrm{W}$ and $408 \mathrm{~m}$ of altitude). The region climate, based on Climate Guide's published data (Embrapa Agropecuária Oeste, 2013) and Köppen classification, is the tropical monsoon
(Am), and the soil in the area is classified as clayey Oxisol (Santos et al., 2013).

The soil chemical characteristics at the $0-0.20 \mathrm{~m}$ layer were as follows: $\mathrm{pH}\left(\mathrm{CaCl}_{2}\right)=6.2 ; \mathrm{Al}=0.0 ; \mathrm{Ca}=$ $6.5 \mathrm{cmol}_{\mathrm{c}} \mathrm{dm}^{-3} ; \mathrm{Mg}=2.8 \mathrm{cmol}_{\mathrm{c}} \mathrm{dm}^{-3} ; \mathrm{H}+\mathrm{Al}_{3}=2.7$ $\mathrm{cmol}_{\mathrm{c}} \mathrm{dm}^{-3} ; \mathrm{K}=1.0 \mathrm{cmol}_{\mathrm{c}} \mathrm{dm}^{-3} ; \mathrm{SB}=10.3 \mathrm{cmol}_{\mathrm{c}} \mathrm{dm}^{-3}$; $\mathrm{CEC}=13.0 \mathrm{cmol}_{\mathrm{c}} \mathrm{dm}^{-3} ; \mathrm{CEC}_{(\mathrm{E})}=10.3 \mathrm{cmol}_{\mathrm{c}} \mathrm{dm}^{-3} ;$ soil base saturation $=79.3 \% ; \mathrm{P}($ Mehlich $)=57.3 \mathrm{mg} \mathrm{dm}^{-3}$; $\mathrm{Cu}=9.1 \mathrm{mg} \mathrm{dm}^{-3} ; \mathrm{Fe}=24.7 \mathrm{mg} \mathrm{dm}^{-3} ; \mathrm{Mn}=98.6 \mathrm{mg}$ $\mathrm{dm}^{-3} ; \mathrm{Zn}=4.7 \mathrm{mg} \mathrm{dm}^{-3}$; organic matter $=37.9 \mathrm{~g} \mathrm{~kg}^{-1}$.

Temperature and precipitation information recorded during the experiment were obtained from the Embrapa Agropecuária Oeste Meteorological Station, which is about $300 \mathrm{~m}$ away from the experimental area (Figure $1)$.

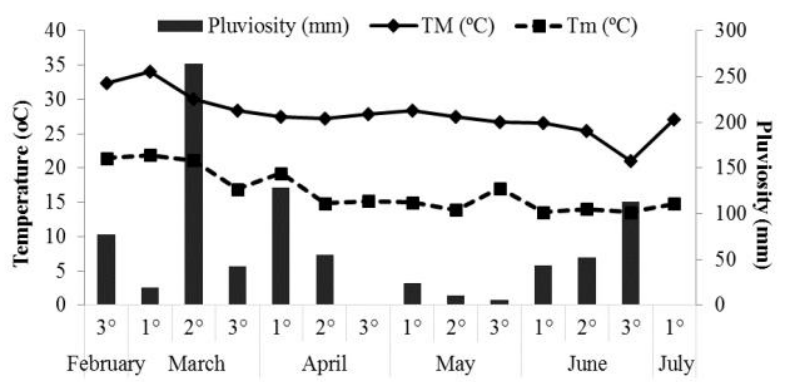

Figure 1. Total precipitation and maximum (TM) and minimum (Tm) temperature every ten days, from 2013's February to July, in Dourados, MS, Brazil. Source: Agrometeorological Station of Embrapa Agropecuária Oeste (2013).

The experimental design was randomized blocks with six replicates, and the treatments were constituted by the combination of spaces between maize rows, alone maize cropping and intercropped with ruzigrass, and ruzigrass seeds distribution methods, as follows: 1) alone maize cropping in $0.45 \mathrm{~m}$ spaced rows (AM45); 2) maize spaced at $0.45 \mathrm{~m}$ rows intercropped with ruzigrass sown in the same row (MBsr); 3) maize spaced at $0.45 \mathrm{~m}$ rows intercropped with ruzigrass sown by broadcasting $(\mathrm{MBHu})$; 4) alone maize cropping in $0.90 \mathrm{~m}$ spaced rows (SM90); 5) maize spaced at $0.90 \mathrm{~m}$ rows intercropped with ruzigrass sown between the rows (MBbr); 6) maize cropping in $0.45 \mathrm{~m}$ and $0.90 \mathrm{~m}$ alternated rows with ruzigrass in the $0.90 \mathrm{~m}$ spaced row (M2B1); and, 7) maize cropping with $0.45 \mathrm{~m}$ and 0.90 $\mathrm{m}$ alternated rows (SM2-0). The sowing of maize (DKB 390 PRO hybrid) was sown on 2013 February 27, in the no-tillage system area, after soybean harvest, with 250 $\mathrm{kg} \mathrm{ha}^{-1}$ of the formulation 10-25-25 NPK. At the same time, the sowing of ruzigrass was conducted in a population of 200,000 plants $\mathrm{ha}^{-1}$ (Ceccon, 2015), using coated seeds. In the hurled way, the ruzigrass seeds were distributed on the soil surface immediately before maize seeding, with twice as many seeds of other treatments. 
The emergence of maize seedlings occurred on March 05, 2013, and after ten days, $40 \mathrm{~kg} \mathrm{ha}^{-1}$ of nitrogen was applied on the topdressing using ammonium sulfate. Thinning followed the row spacing adopted in each cropping systems, with a final population adjustment of 55,000 plants $\mathrm{ha}^{-1}$ (2.5 plants $\mathrm{m}^{-1}$ in the 0.45 spacing; 4.9 plants $\mathrm{m}^{-1}$ on the $0.90 \mathrm{~m}$ spacing; 3.7 plants $\mathrm{m}^{-1}$ in the 0.45 and $0.90 \mathrm{~m}$ merged spacing).

The weed management consisted of pre-sowing desiccation with glyphosate (1.44 L active ingredient ha $\left.{ }^{1}\right)$ and post-emergence application of atrazine $\left(1.5 \mathrm{~L} \mathrm{ha}^{-}\right.$ $\left.{ }^{1}\right)$ in maize intercropped area. Pest control was carried out with Thiamethoxam + Lambda-cyhalothrin $(200 \mathrm{~mL}$ $\mathrm{ha}^{-1}$ ) applicated twenty days after maize emergence.

During maize full flowering, photosynthetic active photons density was evaluated using a Decagon Accupar LP-80 ceptômeter device. Readings were taken between 10 and 12 hours, in the center of the plots floor area, parallel to the planting rows. In the treatments with double rows of maize (SM2-0 and M2B1), readings were performed on the $0.90 \mathrm{~m}$ spaces between rows. Measurements were made at three canopy strata: above maize canopy, at first ear height and the ground level, in three replications.

Photosynthetically active radiations, from the top of canopy to the ear height (RFA-Ear) and on the bottom of the canopy below the ear (RFA-Solo), were determined from collected data. Chlorophyll indices (a, $\mathrm{b}$, and total) were also measured using portable electronic meter Falker model CFL1030. Readings were taken by morning on three plants samples, on the upper opposite leaf surface and below the ear, on the third middle of the leaf blade.

The maize leaves and ear surface temperature were measured at the beginning of the reproductive period, with an infrared light portable digital thermometer device from Incoterms. Readings were taken from 9 to 10 am and from 13 to 14 hours in four parts of the plant: leaves bottom, plant middle and apex and in the ear, with three sub-samples, from which the average leaf temperature of the maize plants was calculated in each experimental unit.

Morphological maize evaluations were measured during R2 stage (blister stage), on five plants per plot, in which plant height, ear insertion height, stem diameter, and leaf area per plant were determined. The leaf area was obtained by measuring the shank leaf length, and base width and plant leaf area was estimated by the equation: 0.75 (adjustment factor) $\times \mathrm{L} \times \mathrm{W} \times$ number of leaves per plant (Pereira, 1987). The leaf area index was calculated by the relation between the plant leaf area and the ground area occupied by the plant.

A subsample of five plants was removed and subjected to drying in a circulating air oven at $65{ }^{\circ} \mathrm{C}$ until constant weight to determine production leaf dry mass, stem dry mass, maize, total dry mass, and dry mass content.

At maize physiological maturity (08/07/2013), there was the count of plants and the collection of ears in two $5 \mathrm{~m}$ long central rows, and the following variables were evaluated: ear diameter, ear length, number of grain rows, maize ear yield, weight of hundred grains and grain yield, with moisture correction to $13 \%$. Ruzigrass plants samples, in $1 \mathrm{~m}$ rows were carried out to determine their height, the number of tillers, and maize dry mass production. Total dry mass of maize and brachiaria was obtained by the sum of the maize leaf, stem, ear and the aerial part of ruzigrass dry weight values.

The data were submitted to variance analysis by $\mathrm{F}$ test $(\mathrm{p}<0.05)$, and when significant, average comparison was performed by Tukey test at $5 \%$ probability using Sisvar program (Ferreira, 2008).

\section{Results and Discussion}

Variance analysis indicated no significant effect of treatments for chlorophyll $a$ content (36.98); maize stem diameter (18.86 $\mathrm{mm})$; leaf area index (5.35); leaf dry mass $(22.21 \%)$; ear diameter $(54.87 \mathrm{~mm})$; ear length $(16.04 \mathrm{~cm})$; number of grain rows (18.02); weight of a hundred grains $(32.0 \mathrm{~g})$ and number of ruzigrass tillers (25.83 per plant). The straw dry mass production, although it had significant effect by the $\mathrm{F}$ test $(\mathrm{P}<0.05)$, it was not different between treatments by the Tukey test, with an average of $9,593 \mathrm{~kg} \mathrm{ha}^{-1}$.

The most photosynthetically active radiation incident, until ear insertion height (PAR-Ear), occurred in double rows of maize intercropped with ruzigrass (M2B1); and for the bottom of the canopy (RFA-Solo) the greater value was reached in the single maize cropping in $0.90 \mathrm{~m}$ spaced rows (SM90) (Table 1). In $0.90 \mathrm{~m}$ spacing, most of the incident solar radiation is lost because it does not reach all the plants equally, and there is also the shading from those located on the same row. The SM90 also showed high levels of total chlorophyll, as a result of the chlorophyll $b$ increasing. Reports indicate that there is chlorophyll $a$ and $b$ increasing in plants that grow under low radiation, increasing the less intense light absorption efficiency and thus keeping active the photosynthetic activity (Martuscello et al., 2009).

The reduced spacing in alone maize cropping (SM45) is characterized by better distribution of plants in the area, contributing to a better utilization of the incident radiation by leaves until ear height, causing the decreasing of PAR-Ear value. Because of the lower photosynthetically active radiation incident on the ground and at ear height, the $0.45 \mathrm{~m}$ spacing methods of 
cultivation, with alone maize cropping (SM45) and intercropped with ruzigrass in a row (MBsr) also had the lowest leaf temperatures (Table 1).

The lowers total chlorophyll values were found when the maize was intercropped with ruzigrass, independent of which spaces were used, mainly in intercropping with ruzigrass sown in row (MBsr) (Table 1). The presence of maize and perennial forage in the same area implies in an increasing of nutrients competition, primarily nitrogen, and can jeopardize the total chlorophyll content in maize leaves, because chlorophyll index correlates positively with leave nitrogen content (Argenta et al., 2001).

The maize intercropped with ruzigrass sown by broadcasting $(\mathrm{MBHu})$ was the cropping system with higher leaf temperatures. The ruzigrass may have contributed to maintain the higher canopy temperature in this system, an important factor in periods of low temperatures, helping to speed up the plant metabolic processes. Considering that the temperature has a great influence on the maize development cycle, determined by the sum of degree-days, this feature may have favored the increase in grain production.

In periods of drought, soil shading caused by the presence of ruzigrass can also benefit the maize. As it reduces evapotranspiration, which associated to their water absorption capacity at greater depths, it allows the moisture to keep in the soil for a longer period. The maize intercropped with ruzigrass sown by broadcasting (MBHu) had the lowers maize plants height (APM), ear insertion height (IEA), and leaf area (Table 2), in response to its treatment's competition between maize and the ruzigrass largest population, during the flowering stage. The drought stress conditions during maize cropping may have affected the internodes length (Magalhães et al., 2002) and can reduce cell growth rate (Kunz et al., 2007). Although the higher maize heights were found in all others consortium systems, the presence of perennial forage could have led to the apical dominance of maize.

Table 1. Photosynthetically active radiation incident at the ear of maize (PAR-Ear) and soil (PAR-Soil), chlorophyll a, total chlorophyll index, and leaf average temperature in maize leaves, in alone maize cropping or intercropped with ruzigrass [Urochloa ruziziensis (R. Germ. \& C.M. Evrard) Crins], in Dourados, MS, Brazil, 2013.

\begin{tabular}{|c|c|c|c|c|c|c|c|c|c|c|}
\hline \multirow{2}{*}{$\begin{array}{l}\text { Cropping systems }{ }^{1} \\
\text { M2B1 }\end{array}$} & \multicolumn{2}{|c|}{$\begin{array}{c}\text { PAR-Ear } \\
\left(\mu \mathrm{mol} \mathrm{m} \mathrm{m}^{-1}\right)\end{array}$} & \multicolumn{2}{|c|}{$\begin{array}{c}\text { PAR-Soil } \\
\left(\mu \mathrm{mol} \mathrm{m} \mathrm{m}^{-1}\right)\end{array}$} & \multicolumn{2}{|c|}{ chlorophyll a } & \multicolumn{2}{|c|}{ Total chlorophyll } & \multicolumn{2}{|c|}{$\begin{array}{l}\text { Leaves temperature } \\
\left({ }^{\circ} \mathrm{C}\right)\end{array}$} \\
\hline & 370.43 & $\mathrm{a}$ & 78.42 & $\mathrm{c}$ & 25.44 & $\mathrm{bc}$ & 62.17 & $a b$ & 22.05 & $\mathrm{a}$ \\
\hline MBbr & 319.51 & $a b$ & 49.15 & $\mathrm{~cd}$ & 26.21 & $a b$ & 62.74 & $a b$ & 22.27 & $\mathrm{a}$ \\
\hline $\mathrm{MBHu}$ & 241.73 & $\mathrm{bc}$ & 41.82 & $\mathrm{~cd}$ & 27.10 & $\mathrm{ab}$ & 64.49 & $\mathrm{a}$ & 22.62 & $\mathrm{a}$ \\
\hline MBsr & 178.43 & $\mathrm{~cd}$ & 31.04 & $\mathrm{~d}$ & 23.77 & $\mathrm{c}$ & 60.43 & $\mathrm{~b}$ & 20.54 & $\mathrm{~b}$ \\
\hline SM2-0 & 134.01 & de & 134.69 & $\mathrm{~b}$ & 26.64 & $a b$ & 63.69 & $\mathrm{a}$ & 22.07 & $\mathrm{a}$ \\
\hline SM45 & 74.62 & $\mathrm{e}$ & 74.95 & $\mathrm{c}$ & 27.10 & $a b$ & 64.43 & $\mathrm{a}$ & 20.36 & $\mathrm{~b}$ \\
\hline SM90 & 240.55 & $\mathrm{bc}$ & 240.55 & $\mathrm{a}$ & 27.85 & $\mathrm{a}$ & 65.04 & $\mathrm{a}$ & 21.41 & $a b$ \\
\hline
\end{tabular}

Averages followed by same letter in the column do not differ by Tukey's test, at $\mathrm{p} \leq 0.05$.

${ }^{1} \mathrm{M} 2 \mathrm{~B} 1$ : maize cropping in $0.45 \mathrm{~m}$ and $0.90 \mathrm{~m}$ alternated rows with ruzigrass in the $0.90 \mathrm{~m}$ spaced row; MBbr: maize spaced at $0.90 \mathrm{~m}$ rows intercropped with ruzigrass sown between the rows; $\mathrm{MBHu}$ : maize spaced at $0.45 \mathrm{~m}$ rows intercropped with ruzigrass sown by broadcasting; MBsr: maize spaced at $0.45 \mathrm{~m}$ rows intercropped with ruzigrass sown in the same rows; SM2-0: maize cropping with $0.45 \mathrm{~m}$ and $0.90 \mathrm{~m}$ alternated rows; SM45: alone maize cropping in $0.45 \mathrm{~m}$ spaced rows; SM90: alone maize cropping in $0.90 \mathrm{~m}$ spaced rows.

Table 2. Maize plant height (MPH), ear insertion height (EIH), ruzigrass plant height (BPH), maize leaf area (MLA), stalks dry matter (SDM) and ear dry matter (EDM) in alone maize cropping or intercropped with ruzigrass [Urochloa ruziziensis (R. Germ. \& C.M. Evrard) Crins], in Dourados, MS, Brazil, 2013.

\begin{tabular}{|c|c|c|c|c|c|c|c|c|c|c|c|c|}
\hline \multirow{2}{*}{$\begin{array}{l}\text { Modalities }^{1} \\
\text { M2B1 }\end{array}$} & \multicolumn{2}{|c|}{ MPH (m) } & \multicolumn{2}{|c|}{ EIH (m) } & \multicolumn{2}{|c|}{$\mathrm{BPH}(\mathrm{m})$} & \multicolumn{2}{|c|}{$\operatorname{MLA}\left(\mathrm{cm}^{2}\right)$} & \multicolumn{2}{|c|}{ SDMC (\%) } & \multicolumn{2}{|c|}{$\operatorname{EDME~}(\%)$} \\
\hline & 2.15 & $\mathrm{a}$ & 1.04 & $\mathrm{Ab}$ & 1.48 & $\mathrm{a}$ & 9.450 & $\mathrm{a}$ & 19.81 & $\mathrm{bc}$ & 39.88 & $\mathrm{~b}$ \\
\hline MBsr & 2.16 & a & 1.04 & $\mathrm{Ab}$ & 1.11 & $\mathrm{~b}$ & 8.773 & $a b$ & 21.26 & $\mathrm{bc}$ & 39.68 & $b$ \\
\hline $\mathrm{MBHu}$ & 1.81 & $\mathrm{c}$ & 0.93 & $\mathrm{~B}$ & 1.23 & $\mathrm{~b}$ & 7.789 & $\mathrm{~b}$ & 21.71 & $a b$ & 43.65 & $\mathrm{a}$ \\
\hline MBbr & 2.16 & $\mathrm{a}$ & 1.09 & A & 1.27 & $\mathrm{~b}$ & 9.172 & $a b$ & 19.00 & $\mathrm{c}$ & 40.30 & $b$ \\
\hline SM45 & 2.01 & $\mathrm{~b}$ & 0.98 & $\mathrm{Ab}$ & - & & 9.224 & $\mathrm{a}$ & 24.03 & $\mathrm{a}$ & 41.71 & $\mathrm{a}$ \\
\hline SM2-0 & 2.14 & $a b$ & 1.02 & $\mathrm{Ab}$ & - & & 9.851 & $\mathrm{a}$ & 19.33 & $\mathrm{bc}$ & 44.55 & $\mathrm{a}$ \\
\hline SM90 & 2.03 & $a b$ & 0.99 & $\mathrm{Ab}$ & - & & 8.437 & $a b$ & 19.47 & $\mathrm{bc}$ & 39.34 & $b$ \\
\hline
\end{tabular}

Averages followed by the same letters in the column do not differ by Tukey's test, at $\mathrm{p} \leq 0.05$.

${ }^{1} \mathrm{M} 2 \mathrm{~B} 1$ : maize cropping in $0.45 \mathrm{~m}$ and $0.90 \mathrm{~m}$ alternated rows with ruzigrass in the $0.90 \mathrm{~m}$ spaced row; MBbr: maize spaced at $0.90 \mathrm{~m}$ rows intercropped with ruzigrass sown between the rows; $\mathrm{MBHu}$ : maize spaced at $0.45 \mathrm{~m}$ rows intercropped with ruzigrass sown by broadcasting; MBsr: maize spaced at $0.45 \mathrm{~m}$ rows intercropped with ruzigrass sown in the same rows; SM2-0: maize cropping with $0.45 \mathrm{~m}$ and $0.90 \mathrm{~m}$ alternated rows; SM45: alone maize cropping in $0.45 \mathrm{~m}$ spaced rows; SM90: alone maize cropping in $0.90 \mathrm{~m}$ spaced rows. 
The leaf area per plant was higher in the double rows of maize cropping (SM2-0 and M2B1), regardless of the presence of ruzigrass (Table 2). In these treatments with higher spacing, the increasing leaf area allows it to maximize the light capture and promote a positive carbon balance in response the lower light interception and to the plant self-shadowing on the row (Jakelaitis et al., 2006).

The highest maize dry matter and ears weight content and the higher maize dry matter production occurred in reduced spacing arrangements (Tables 2 and 3 , respectively), which are the alone maize cropping (SM45) and maize intercropped with ruzigrass sown by broadcasting (MBHu). The maximizing of radiation interception, achieved with better distribution of plants, allows it to raise the potential of maize dry matter production, even in the intercropping. However, maize on $0.90 \mathrm{~m}$ spacing had the lowest percentages of dry matter, regardless of alone cropping or intercropping. The intercropped arrangements with $0.90 \mathrm{~m}$ spacing (M2B1 and MBbr) had the lowest yields of the total dry mass of maize.
The maize intercropped in double rows (M2B1), besides presenting higher plant height (Table 2), also had the highest ruzigrass dry matter yield (Table 4 ). The highest light incidence between the rows, provided by the arrangement of plants, resulted in greater maize stems and elongation of ruzigrass leaves. As found before, in larger row spacing, the ruzigrass competition potential is higher than the maize crop, which can affect the mass increasing of the grain crop (Ferreira, 2015).

The other arrangement of the consortium system, ruzigrass sown in row (MBsr), between the row (MBbr) and broadcasting $(\mathrm{MBHu})$, showed no significant difference between them, both in ruzigrass plant height and dry matter productivity, because shading caused by maize plants can stabilize the grass growth and affect the biomass accumulation, resulting in a lower dry matter weight (Table 4).

Cropping systems influenced in determining the number of grains per ear and grain yield (Table 4 ). The highest yields were observed on systems with reduced spacing $(0.45 \mathrm{~m})$, differing significantly from those with $0.90 \mathrm{~m}$ rows spacing.

Table 3. Leaf dry mass (LDM), stem dry mass (SDM), ear dry mass (EDM), and total maize dry mass (TMDM) in alone maize cropping or intercropped with ruzigrass [Urochloa ruziziensis (R. Germ. \& C.M. Evrard) Crins], in Dourados, MS, Brazil, 2013.

\begin{tabular}{|c|c|c|c|c|c|c|c|c|}
\hline Modalities $^{1}$ & \multicolumn{2}{|c|}{$\operatorname{LDM}\left(\mathrm{kg} \mathrm{ha}^{-1}\right)$} & \multicolumn{2}{|c|}{$\operatorname{SDM}\left(\mathrm{kg} \mathrm{ha}^{-1}\right)$} & \multicolumn{2}{|c|}{$\operatorname{EDM}\left(\mathrm{kg} \mathrm{ha}^{-1}\right)$} & \multicolumn{2}{|c|}{ TMDM $\left(\mathrm{kg} \mathrm{ha}^{-1}\right)$} \\
\hline M2B1 & 1.824 & $\mathrm{~b}$ & 3.873 & $\mathrm{~b}$ & 6.581 & $\mathrm{c}$ & 12.279 & $\mathrm{~d}$ \\
\hline MBsr & 2.343 & $\mathrm{a}$ & 4.957 & $\mathrm{a}$ & 8.556 & $a b$ & 15.856 & $a b c$ \\
\hline $\mathrm{MBHu}$ & 2.068 & $a b$ & 4.597 & $a b$ & 8.662 & $a b$ & 15.328 & $\mathrm{bc}$ \\
\hline MBbr & 2.146 & $a b$ & 4.131 & $\mathrm{~b}$ & 7.735 & $\mathrm{bc}$ & 14.013 & $\mathrm{~cd}$ \\
\hline SM45 & 2.470 & $\mathrm{a}$ & 5.050 & $\mathrm{a}$ & 9.895 & $\mathrm{a}$ & 17.417 & $\mathrm{a}$ \\
\hline SM2-0 & 2.271 & $a b$ & 4.886 & $\mathrm{a}$ & 9.867 & $\mathrm{a}$ & 17.025 & $a b$ \\
\hline SM90 & 2.481 & $\mathrm{a}$ & 4.921 & $\mathrm{a}$ & 8.650 & $a b$ & 16.053 & $a b$ \\
\hline
\end{tabular}

Averages followed by equal letters in the column do not differ by Tukey's test, at $p \leq 0.05$.

${ }^{1} \mathrm{M} 2 \mathrm{~B} 1$ : maize cropping in $0.45 \mathrm{~m}$ and $0.90 \mathrm{~m}$ alternated rows with ruzigrass in the $0.90 \mathrm{~m}$ spaced row; MBbr: maize spaced at $0.90 \mathrm{~m}$ rows intercropped with ruzigrass sown between the rows; $\mathrm{MBHu}$ : maize spaced at $0.45 \mathrm{~m}$ rows intercropped with ruzigrass sown by broadcasting; MBsr: maize spaced at $0.45 \mathrm{~m}$ rows intercropped with ruzigrass sown in the same rows; SM2-0: maize cropping with $0.45 \mathrm{~m}$ and $0.90 \mathrm{~m}$ alternated rows; SM45: alone maize cropping in $0.45 \mathrm{~m}$ spaced rows; SM90: alone maize cropping in $0.90 \mathrm{~m}$ spaced rows.

Table 4. Ruzigrass plant dry mass (RPDM), maize yield (MY), and grains per ear (GPE) in alone maize cropping or intercropped with ruzigrass [Urochloa ruziziensis (R. Germ. \& C.M. Evrard) Crins], in Dourados, MS, Brazil, 2013.

\begin{tabular}{lcccccc}
\hline Modalities $^{1}$ & \multicolumn{2}{c}{ RPDM $_{\left(\mathrm{kg} \mathrm{ha}^{-1}\right)}$} & \multicolumn{2}{c}{$\mathrm{MY}\left(\mathrm{kg} \mathrm{ha}^{-1}\right)$} & \multicolumn{2}{c}{ GPE } \\
\hline M2B1 & 1.624 & $\mathrm{a}$ & 433 & $\mathrm{c}$ & 7.153 & $\mathrm{bc}$ \\
MBsr & 0.520 & $\mathrm{~b}$ & 517 & $\mathrm{abc}$ & 8.288 & $\mathrm{abc}$ \\
MBHu & 0.534 & $\mathrm{~b}$ & 548 & $\mathrm{ab}$ & 8.572 & $\mathrm{ab}$ \\
MBbr & 0.396 & $\mathrm{~b}$ & 450 & $\mathrm{bc}$ & 7.011 & $\mathrm{c}$ \\
SM45 & - & & 591 & $\mathrm{a}$ & 9.433 & $\mathrm{a}$ \\
SM2-0 & - & & 475 & $\mathrm{bc}$ & 7.867 & $\mathrm{bc}$ \\
SM90 & - & & 454 & $\mathrm{bc}$ & 7.016 & $\mathrm{c}$ \\
\hline
\end{tabular}

Average followed by the same letter in the column do not differ by Tukey's test, at $\mathrm{p} \leq 0.05$.

${ }^{1} \mathrm{M} 2 \mathrm{~B} 1$ : maize cropping in $0.45 \mathrm{~m}$ and $0.90 \mathrm{~m}$ alternated rows with ruzigrass in the $0.90 \mathrm{~m}$ spaced row; MBbr: maize spaced at $0.90 \mathrm{~m}$ rows intercropped with ruzigrass sown between the rows; $\mathrm{MBHu}$ : maize spaced at $0.45 \mathrm{~m}$ rows intercropped with ruzigrass sown by broadcasting; MBsr: maize spaced at $0.45 \mathrm{~m}$ rows intercropped with ruzigrass sown in the same rows; SM2-0: maize cropping with $0.45 \mathrm{~m}$ and $0.90 \mathrm{~m}$ alternated rows; SM45: alone maize cropping in $0.45 \mathrm{~m}$ spaced rows; SM90: alone maize cropping in $0.90 \mathrm{~m}$ spaced rows. 
Alone maize cropping with $0.45 \mathrm{~m}$ spacing (SM45) has provided the highest number of grains per ear and the highest grain yield. As reported by Marchão et al. (2006), the best plant distribution in area, using reduced spacing, is decisive in maize grain yield. In arrangements with $0.90 \mathrm{~m}$ row spacing, there is a greater plants density in row and reduced efficiency in incident radiation interception. When the photosynthetic activity is compromised, there is a reduction in carbohydrates production, and as a result, a smaller volume of compounds is designated for grain filling (Magalhães et al., 2002). Also, competition for assimilates limits the grain production capacity and affects the final number of grains per ear (Sangoi et al., 2013).

The results show that modifying the spatial arrangement of plants, even in intercropping, can increase maize yield. Some authors found that, in many cases, there can be no significant difference between the yield of the alone maize cropping and intercropped with forages, which depends on the combination of several factors, including the perennial forage population, the time of its implementation and planting arrangements (Jakelaitis et al., 2006; Resende et al., 2008; Freitas et al., 2015). Over the years, the adoption of the consortium results in higher amount of straw, increases soil organic matter, and both off-season and the summer crop cultivation productivity tend to rise.

\section{Conclusions}

Farming arrangements more influenced the morphological and physiological characteristics and maize ears productivity than the presence of ruzigrass The reduced spacing systems has greater use of solar radiation and provides increases in either grain yield and dry matter, regardless of the alone maize cropping or in intercropped with ruzigrass, due to better plant arrangement in the area.

The higher photosynthetically active radiation found in the double maize intercropping provides higher plant height and higher dry mass production of forage.

\section{Bibliographic References}

Argenta, G., Silva, P.R.F., Bortolini, C.G., 2001. Teor de clorofila na folha como indicador do nível de $\mathrm{N}$ em cereais. Ciência Rural, 31(4), 715-722.

Ceccon, G., 2015. Cálculo para taxa de semeadura de espécies forrageiras perenes em cultivos anuais. Revista Agrarian, 27(8), 39-46.

Ceccon, G., Borghi, E., Crusciol, C.A.C., 2013a. Modalidades e métodos de implantação do consórcio milho-braquiária, em: Ceccon G., Consórcio Milho-Braquiária, p. 27-46.
Ceccon, G, Staut, L.A., Sagrilo, E., Machado, L.A.Z., Nunes, D.P., Alves, V.B., 2013b. Legumes and forage species sole or intercropped with corn in soybean-corn Succession in midwestern Brazil. Revista Brasileira de Ciência do Solo, 37(1), 204-212.

Chioderoli, C.A., Mello, L.M.M., Grigolli, P.J., Furlani, C.E.A., Silva, J.O.R., Cesarin, A.L., 2012. Atributos físicos do solo e produtividade de soja em sistema de consórcio milho e braquiária. Revista Brasileira de Engenharia Agrícola e Ambiental, 16(1), 37-43.

Concenço, G., Ceccon, G, Correia, I.V.T., Leite, L.F., Alves, V.B., 2013. Ocorrência de espécies daninhas em função de sucessões de cultivo. Planta Daninha, 31(2), 359-368.

Embrapa Agropecuária Oeste, 2013. Guia Clima. Dourados, MS. http://clima.cpao.embrapa.br/ (Accessed April 15, 2015).

Ferreira, D.F., 2008. SISVAR: um programa para análises e ensino de estatística. Revista Symposium, 6(2), 36-41.

Ferreira, E.A., Matos, C.C., Barbosa, E.A., Melo, C.A.D., Silva, D.V., Santos, J.B., 2015. Aspectos fisiológicos de soja transgênica submetida à competição com plantas daninhas. Revista de Ciências Agrárias, 58(2), 115-121.

Freitas, M.A.M., Silva, D.V., Souza, M.F., Silva, A.A., Saraiva, D.T., Freitas, M.M., Cecon, P.R., Ferreira, L.R., 2015. Levels of nutrients and grain yield of maize intercropped with signalgrass (Brachiaria) in different arrangements of plants. Planta Daninha, 33(1), 49-56.

Garcia, C.M.P., Andreotti, M., Teixeira Filho, M.C.M., Buzetti, S., Celestrino, T.S., Lopes, K.S.M., 2013. Desempenho agronômico da cultura do milho e espécies forrageiras em sistema de Integração Lavoura-Pecuária no Cerrado. Ciência Rural, 43(4), 589-595.

Jakelaitis, A., Silva, A.F., Pereira, J.L., Silva, A.A., Ferreira, L.R., Vivian, R., 2006. Efeitos da densidade e época de emergência de Brachiaria brizantha em competição com plantas de milho. Acta Scientiarum Agronomy, 28(3), 373378.

Kappes, C., Andrade, J.A.C., Arf, O., Oliveira, A.C., Arf, M.V., Ferreira, J.P., 2011. Desempenho de híbridos de milho em diferentes arranjos espaciais de plantas. Bragantia, 70(2), 334-343.

Kunz, J.H., Bergonci, J.I., Bergamaschi, H., Dalmago, G.A., Heckler, B.M.M., Comiran, F., 2007. Uso da radiação solar pelo milho sob diferentes preparos do solo, espaçamento e disponibilidade hídrica. Pesquisa Agropecuária Brasileira, 42(11), 1511-1520.

Loss, A., Pereira, M.G., Beutler, S.J., Perin, A., Anjos, L.H.C., 2012. Densidade e fertilidade do solo sob sistemas de plantio direto e de integração lavoura-pecuária no Cerrado. Revista de Ciências Agrárias - Amazon Journal of Agricultural and Environmental Sciences, 55(4), 260-268.

Magalhães, P.C., Durães, F.O.M., Carneiro, N.P., Paiva, E., 2002. Fisiologia do Milho. Circular Técnica, 22. Sete Lagoas: Embrapa Milho e Sorgo, 23 p.

Marchão, R.L., Brasil, E.M., Ximenes, P.A., 2006. Interceptação da radiação fotossinteticamente ativa e 
rendimento de grãos do milho adensado. Revista. Brasileira de Milho e Sorgo, 5(2), 170-181.

Martuscello, J.A., Jank, L., Gontijo Neto, M.M., Laura, V.A., Cunha, D.N.F.V., 2009. Produção de gramíneas do gênero Brachiaria sob níveis de sombreamento. Revista Brasileira de Zootecnia, 38(7), 1183-1190.

Pereira, A.R., 1987. Estimativa da área foliar em milharal. Bragantia, 46(1), 147-150.

Resende, A.V., Shiratsuchi, L.S., Fontes, J.R.A., Arns, L.L.K., Ribeiro, L.F., 2008. Adubação e arranjo de plantas no consórcio milho e braquiária. Pesquisa Agropecuária Tropical, 38(4), 269-275.
Sangoi, L., Zanin, C.G., Schmitt, A., Vieira, J., 2013. Senescência foliar e resposta de híbridos de milho liberados comercialmente para cultivo em diferentes épocas ao adensamento. Revista Brasileira de Milho e Sorgo, 12(1), 2132 .

Santos, H.G., Jacomine, P.K.T., Anjos, L.H.C., Oliveira, V.A., Lumbreras, J.F., Coelho, M.R., Almeida, J.Á., Cunha, T.J.F., Oliveira, J.B., 2013. Sistema brasileiro de classificação de solos, terceira ed. Embrapa Solos, Rio de Janeiro.

Strieder, M.L., Silva, P.R.F., Rambo, L., Bergamaschi, H., Dalmago, G.A., Endrigo, P.C., Jandrey, D.B., 2008. Características de dossel e rendimento de milho em diferentes espaçamentos e sistemas de manejo. Pesquisa Agropecuária Brasileira, 43(3), 309-317. 